Martina Petranović

Odsjek za povijest hrvatskog kazališta HAZU, Zagreb

martina_petranovic@yahoo.com

(D) https://orcid.org/0000-0002-9368-0353

\title{
Kulturna mobilnost i izbori suvremene hrvatske drame na stranim jezicima ${ }^{1}$
}

\author{
Cultural mobility and selections of contemporary \\ Croatian plays in foreign languages
}

Sažetak: U radu se analiziraju hrestomatije, antologije i izbori suvremene hrvatske drame na stranim jezicima objavljeni od 1990. godine do danas u Hrvatskoj i inozemstvu. Rad je usredotočen na utvrđivanje i proučavanje motiva priređivača i antologičara te naravi, strukture, strategija i dosega objavljenih publikacija, s posebnim osvrtom na problematiku kulturne mobilnosti i kanonizacije suvremene hrvatske dramske produkcije.

Ključne riječi: izbori suvremene hrvatske drame, kulturna mobilnost, književni kanon, hrvatsko kazalište

Summary: The paper examines the chrestomathies, anthologies and selections of contemporary Croatian plays in foreign languages published from 1990 until today in Croatia and abroad. The paper focuses on the motives of editors and authors of anthologies, as well as nature, structure, strategies and accomplishments of available drama selections, with special regard to the topics of cultural mobility and canonisation of contemporary Croatian drama.

Keywords: selections of contemporary Croatian plays, cultural mobility, canon formation, Croatian theatre

Prijevodi suvremene hrvatske drame na strane jezike kontinuirana su sastavnica hrvatskoga kazališnoga života, a u ovom će se radu preispitati priređivački koncepti izbora suvremene hrvatske drame na strane jezike na-

${ }^{1}$ Rad je napisan u sklopu znanstvenoga projekta Politike identiteta i hrvatska drama od 1990. do 2016. koji financira Hrvatska zaklada za znanost (broj projekta: IP-2016-06-4316, voditelj projekta: prof. dr. sc. Zlatko Kramarić). 
stalih od 1990. godine do danas u Hrvatskoj i inozemstvu te njihovi učinci na reprezentaciju jednoga dijela suvremenoga hrvatskog dramskog korpusa za inozemstvo kao i povratno djelovanje tih izbora na nacionalnu književnu i kazališnu historiografiju. Kada je riječ o suvremenoj hrvatskoj drami napisanoj u razdoblju od osamostaljenja Hrvatske do danas, veći se broj prevedenih naslova, i samostalno i u skupnim izborima dramskih djela, ponajprije veže uz novo tisućljeće. Prve naznake ulaska danas aktualnih dramskih pisaca $\mathrm{u}$ izbore suvremene hrvatske drame na stranim jezicima nalazimo još krajem osamdesetih i sredinom devedesetih godina prošloga stoljeća, primjerice $\mathrm{u}$ izboru hrvatske poslijeratne drame na talijanskom jeziku Il teatro croato del dopoguerra (1989.)² koji su načinili Nikola Batušić, Branko Hećimović i Ranko Marinković, uvrstivši i ulomak Gavranove Kreontove Antigone, te u izboru deset hrvatskih jednočinki na esperantu Antologio de kroataj unuaktaj dramoj (1997.) koji je sastavio Branko Hećimović, uvrstivši u nj i Gavranove Ljubavi Georgea Washingtona ${ }^{3}$. Međutim, sustavniji rad na izboru suvremene hrvatske dramske produkcije za inozemne kulturne i kazališne sredine, pa i za inozemna tržišta koja u novom tisućljeću posebice dobivaju na važnosti s obzirom na učinke vladavine globalnoga kapitala i tržišnoga preustroja kulturne proizvodnje i potražnje, započeo je u prvim godinama 21. stoljeća, u korak sa sve izraženijom fizičkom i metaforičkom globalizacijom i mobilnošću društva na svjetskoj razini. U isto vrijeme, uostalom, započinje i rad na reprezentativnim izborima, hrestomatijama i antologijama suvremene hrvatske dramske produkcije na hrvatskome jeziku: početkom novoga tisućljeća objavljeni su Senkerova Hrestomatija novije hrvatske drame (1941.-1995.) (2001.)4 i Bokin izbor iz hrvatske drame devedesetih Nova hrvatska drama (2002.). Uz spomenute dvije knjige na hrvatskome su jeziku početkom novoga tisućljeća tiskani i prvi izbori suvremene hrvatske drame na stranim jezicima, a konačni zbroj zasad tvore izbori drame na makedonskom, engleskom, njemačkom, poljskom, mađarskom, francuskom i španjolskom jeziku' ${ }^{6}$, obilježeni većim ili manjim stupnjem antologijskih pretenzija, katkada i s deklarativnim pa i apodiktičnim odbijanjem takve primisli. Prvi je takav izbor 2002. potpisala Sanja Nikčević sastavivši na makedonskome jeziku zbirku Antologija na novata hrvatska drama / Antologija novije hrvatske drame ${ }^{7}$ a već je iduće 2003. Boris Senker načinio izbor suvremene hrvatske drame na engleskome

2 Il teatro croato del dopoguerra. Ur. N. Batušić, B. Hećimović i R. Marinković. „La battana“ 1989, br. 91-92.

3 Antologio de kroataj unuaktaj dramoj. Ur. B. Hećımović. Zagreb 1997.

${ }^{4}$ B. Senker: Hrestomatija novije hrvatske drame (1941.-1995.). Zagreb 2001.

${ }^{5}$ J. Воко: Nova hrvatska drama. Zagreb 2002.

${ }^{6}$ U pripremi su i dva izbora hrvatske drame na poljskom jeziku (Varšava, Katowice).

7 S. NiKČEvić: Antologija na novata hrvatska drama. Skopje 2002. 
jeziku sugestivno ga naslovivši Different voices / Različiti glasovi ${ }^{8}$. Nakon kraće stanke, tijekom koje je objavljen i Rafoltov izbor suvremene hrvatske drame na hrvatskome jeziku Odbrojavanje (2007.) istodobno si i prisvajajući (u podnaslovu) i odričući (u predgovoru) teret antologijskoga odabira', krajem prvog i početkom drugog desetljeća 21. stoljeća uslijedio je svojevrsni drugi val prebiranja ili rezimiranja aktualne domaće dramske produkcije $z a$ inozemne sredine, ali i $u$ inozemnim sredinama. U izboru Waltera Kootza u Beču je na njemačkome jeziku 2009. otisnuta zbirka hrvatskih drama pod naslovom Eine Verdammt Glückliche Familie / Prokleto sretna obitelj ${ }^{10}$. Ivan Trojan 2012. priredio je zbirku Tranzit, antologiju hrvatskih dramskih tekstova na mađarskome jeziku ${ }^{11}$. Iste je godine $u$ Katowicama na poljskome jeziku otisnut izbor hrvatskih drama napisanih od 1990. nadalje, a izbor su, prema spomenutom Rafoltovu Odbrojavanju priredili Leszek Małczak, Anna Ruttar i Katarzyna Majdzik $^{12}$. Nataša Govedić je, također 2012., na francuskome jeziku priredila hrestomatiju hrvatske drame pod naslovom Une parade de cirque / Cirkuska parada ${ }^{13}$. Naposljetku, 2013. objavljena je zbirka Siete dramas croatas contemporaneos / Sedam suvremenih hrvatskih drama, Lukićev odabir suvremenih hrvatskih dramskih tekstova za španjolsko govorno područje ${ }^{14}$. Probuđeni interes toga golemog kazališnog prostora za hrvatsku dramsku književnost, nastao i kao neposredna posljedica festivalskih gostovanja predstava prema djelima suvremenih hrvatskih dramatičara te prevoditeljskoga i uredničkoga angažmana nekolicine pojedinaca (u prvome redu prevoditeljice Nikoline Židek i urednice Željke Turčinović), rezultirao je i najnovijim izborom hrvatske suvremene drame na stranim jezicima, ponovno dakle na španjolskom jeziku, u odabiru Željke Turčinović i pod naslovom Teatro Croato Contemporaneo / Suvremeni hrvatski teatar (2017.) ${ }^{15}$.
8 B. Senker: Different voices. Zagreb 2003.
${ }^{9}$ L. RAfolt: Odbrojavanje. Antologija suvremene hrvatske drame. Zagreb 2007.
${ }^{10}$ W. Kоотz: Eine Verdammt Glückliche Familie. Beč 2009.
11 I. Trojan: Tranzit: Kortárs horvát drámák antológiája. Pecs 2012.
12 L. Maєczak et al.: Kroatywni. Dramat chorwacki po 1990 roku. Wybór tekstów. Sv. 1-2. Katowice 2012.

${ }^{13}$ N. Govedić: Une parade de cirque. Paris 2012.

${ }^{14}$ D. Lukić: Siete dramas croatas contemporaneos. Buenos Aires 2013.

15 Ž. Turčınović: Teatro Croato Contemporaneo. Madrid 2017. U međuvremenu je, dakako, preveden i objavljen cijeli niz dramskih djela u različitim časopisnim izdanjima i zasebnim knjigama drama pojedinoga autora, no ja ću se u ovome radu usredotočiti u prvome redu na prijevode suvremene hrvatske drame skupljene i objavljene u zasebnim zbirkama prevedenih hrvatskih dramskih tekstova različitih autora, a ne na pojedinačne naslove i zbirke djela jednoga autora na stranim jezicima, koje također nisu zanemarive, kao ni povremena časopisna predstavljanja suvremene hrvatske drame, bilo pojedinačnih autora, bilo skupina autora, u Mostu, Hrvatskom kazalištu, Fantomu slobode i sličnim publikacijama. 
Razmatrajući navedeni korpus, čini se potrebnim odmah na početku skrenuti pozornost na nekoliko pojedinosti. Najprije, među spomenutim izdanjima valja razlikovati tri skupine. Prvu skupinu čine izbori hrvatskih priređivača i izdavača, no zasad je riječ o tek jednom izdanju, zbirci što ju je priredio B. Senker, a objavio Hrvatski centar ITI. Druga su - ujedno i središnja i najbrojnija skupina - izbori koje potpisuju hrvatski priređivači u suradnji sa stranim izdavačima (izbori Sanje Nikčević, Ivana Trojana, Nataše Govedić, Darka Lukića i Željke Turčinović). Treća se skupina sastoji od izbora stranih priređivača i stranih izdavača, a također je riječ o samo jednom izdanju urednika Waltera Kootza i bečkog izdavača Kaiser Verlag iz 2009. godine. Svojevrsna je kategorija za sebe poljska zbirka hrvatskih drama iz 2012., modelirana prema Rafoltovu Odbrojavanju, uz nekoliko ipak ne posve neznatnih izmjena i dopuna, ponajviše s obzirom na već postojeće i dostupne prijevode suvremenih hrvatskih drama na poljski jezik (zasebne zbirke drama Mire Gavrana), ali i potencijalnu razumljivost i prijemčivost ispuštenih, odnosno zamjenskih dramskih djela (primjerice, ispušteni Fritzspiel, umetnuta Diva).

U svome manifestu o kulturnoj mobilnosti, Stephen Greenblatt ističe važnost identificiranja i analiziranja tzv. „,kontaktnih zona“ za kulturnu razmjernu $^{16}$. Kada je riječ o izborima hrvatskih drama na stranim jezicima, nalazimo ih među nakladnicima, obrazovnim ustanovama, teatrolozima, urednicima i prevoditeljima. Na popisu nakladnika navedenih publikacija nalaze se ustanove različitih profila i statusa, od većih ili manjih izdavačkih kuća preko udruga do sveučilišta, mahom iz inozemstva, no i domaćih, nerijetko specijaliziranih upravo za prevođenje i publiciranje književnih djela iz drugih nacionalnih i kulturnih sredina. Jedan je od nakladnika hrvatska udruga specijalizirana, među ostalim, i za promoviranje hrvatske drame i kazališta u inozemstvu, Hrvatski centar ITI, ujedno i najpropulzivniji, premda ne i jedini, domaći izdavač hrvatske suvremene drame na hrvatskom i na stranim jezicima. Važnu nakladničku ulogu odigrala su i sveučilišta kao što su Fakultet dramskih umjetnosti u Skopju ili Šlesko sveučilište u Katowicama, kao i nakladničke kuće poput bečkoga Keiser Verlaga, pečuškoga Jelenkora, argentinskoga Biblosa ili pariškoga L'espace d'un instant. Pritom nije posve nevažno da je, primjerice, potonji nakladnik fokusiran na izdanja iz istočne Europe i da je objavio i druga djela hrvatskih dramskih autora, kao što su I. Brešan, S. Šnajder i A. Srnec Todorović.

Kad je riječ o kulturnim mehanizmima koji su pridonosili objavljivanju izbora hrvatskih drama na stranim jezicima, lako je uočiti da su dosadašnji izbori mahom rezultat višegodišnjih i upornih nastojanja hrvatskih i inozemnih urednika, prevoditelja, književnih i kazališnih kritičara, sveučiliš-

16 S. Greenblatt: A mobility studies manifesto. U: Idem et al.: Cultural Mobility: A Manifesto. Cambridge 2009, s. 250-253. 
nih profesora i istraživača koji su na različite načine i kroz različite forme, kontinuirano i takoreći u stopu pratili hrvatsku dramsku produkciju, te su u pravilu i snažno markirani njihovim priređivačkim osobnostima i profesionalnim preferencijama. Na tragu višedesetljetnog konsenzusa brojnih proučavatelja književne historiografije predvođenih Rolandom Barthesom da "neutralnog čitanja nema“"17, prilikom razmatranja dramskih zbirki na stranim jezicima treba stoga imati na umu i, primjerice, kategorije kao što su priređivački motivacijski sklopovi i ciljevi, čitateljske kompetencije, dominantna interesna područja, književne i/ili kazališne poetičke preferencije i estetička stajališta, metodološke pretpostavke, teorijska utemeljenja, ideološka pa i svjetonazorska opredjeljenja, iskustveno sudjelovanje u kazališnoj praksi, i slično ${ }^{18}$. U tom pogledu već na početku valja apostrofirati dvije voditeljice Hrvatskoga centra ITI, najprije Sanju Nikčević, a potom i Željku Turčinović: obje su se, svaka u svoje vrijeme i na svoj način, istaknule ne samo kao voditeljice Centra koje oblikuju i usmjeravaju njegovo djelovanje te kao urednice ili poticateljice tuđih izbora, već i kao samostalne priređivačice pojedinih izbora o kojima će biti riječi u nastavku. Za kulturnu mobilnost hrvatskih dramskih tekstova posebno su se važnima pokazali hrvatski prevoditelji i urednici profesionalno aktivni u inozemnim sredinama, poput prevoditeljica Nikoline Židek (španjolsko govorno područje) i Alide Bremer (njemačko govorno područje), odnosno tzv. francuskoga kruga (Miloš Lazin, Nicolas Raljević i Ives Alexander Tripković). Primjerice, prevoditeljica Nikolina Židek na španjolski je jezik prevela niz suvremenih hrvatskih dramskih djela, ali i potaknula i omogućila njihovo ukoričenje pa i izvođenje u sredinama španjolskoga govornog područja ${ }^{19}$. Za predstavljanje hrvatskih autora $\mathrm{u}$ francuskoj sredini posljednjih se godina od presudnoga značenja pokazalo djelovanje prevoditelja i redatelja Miloša Lazina i njegovih istomišljenika poput Nicolasa Raljevića ili Ivesa Alexandera Tripkovića ${ }^{20}$. Izbor hrvatske drame na makedonskome jeziku potaknula je urednica Jelena Lužina, profesorica i dugogodišnja proučavateljica hrvatskih i makedonskih kazališnih umjetnika te hrvatsko-makedonskih kazališnih veza. Prevođenju hrvatske drame na njemački jezik pridonijeli su napori prevoditeljice i urednice Alide Bremer: premda sama nije potpisala izbor hrvatskih drama na njemačkome jeziku objavljenih u Beču, urednički odabir Waltera Kootza jedan je od re-

17 I. Žužul: Izmišljanje književnosti. Učinci fikcije u povijestima hrvatske književnosti. Zagreb 2019, s. 10.

${ }^{18}$ M. Petranović: Kazalište i (pri)povijest. Ogledi o hrvatskoj kazališnoj historiografiji. Zagreb 2015.

19 N. Žıрек: Hrvatska drama na salonu kazališne knjige u Madridu. „Kazalište“ 2018, br. 21 (75-76), s. 68-71.

${ }^{20}$ O tome usporedi članak B. Senkera: Nastojanja pariškog kruga. U: Krležini dani u Osijeku 2016. Hrvatska drama i kazalište u inozemstvu, drugi dio. Zagreb-Osijek 2017, s. 191-211. 
zultata projekta i serije knjiga „Hrvatska književnost sadašnjice: Projekt Alide Bremer i KulturKontakta Austria“. Hrvatskoj su kazališnoj javnosti nešto slabije poznati priređivači i urednici njemačkoga izbora hrvatskih dramskih djela, kritičar i dramaturg Walter Kootz i autorica jednog od predgovora izboru, književnica i novinarka Jagoda Marinić.

Neovisno o izbornicima i izdavačima - hrvatskim ili stranim, ne treba zaboraviti da su neke od spomenutih zbirki bile financijski potpomognute i od strane hrvatskih institucija, ponajprije Ministarstva kulture i pojedinih gradova, a ponekad su bile i ishodi kulturnih ili znanstvenih projekata sveučilišnih katedri, bilateralnih institucionalnih i programskih suradnji i projekata stranih i domaćih kulturnih i kazališnih centara te razmjene književnih djela i autora, doduše rjeđe unutar šireg nacionalnoga okvira, a češće na razini osobnih entuzijazama i agilnih sredina. Utoliko su i odabiri jezika na koji će drame biti prevedene i sredina u kojima će biti objavljene proizvoljni iz šire perspektive neke zamišljene i obuhvatne nacionalne strategije, a duboko ukorijenjeni $\mathrm{u}$ individualno djelovanje pojedinih ustanova/udruga i pojedinaca $^{21}$. Uzmimo nekoliko primjera. Antologija hrvatske drame na makedonskome jeziku nastavak je uzajamne suradnje institucija u dvjema zemljama te je nakon objavljivanja suvremenih makedonskih drama na hrvatskome jeziku (Antologija nove makedonske drame, Hrvatski centar ITI - UNESCO, Zagreb 2000.) realiziran i uzvratni prevoditeljsko-izdavački projekt ${ }^{22}$. Izbor hrvatske drame na njemačkom jeziku potaknuli su prevoditeljica Alida Bremer i austrijski centar KulturKontakt na čelu s Annemarie Türk, a projekt je umnogome određen okvirom protežnoga istraživanja književne proizvodnje u državama istočne i jugoistočne Europe i prethodnog upoznavanja austrijske zajednice s ostvarenjima Rumunjske, Poljske i Mađarske, pa je tako i, primjerice, predstavljanje zbirke u Beču bilo uklopljeno u program gostovanja Zagrebačkoga kazališta mladih s hrvatskim predstavama u bečkome Volkstheateru „Najbolje s Istoka!“. Antologija hrvatske drame na mađarskome jeziku jedan je od ishoda kulturološkog i književnoznanstvenog međunarodnog projekta „Baranya \& Slavonia“ čiji je nositelj bila Katedra za hrvatsku književnost Filozofskog fakulteta Sveučilišta Josipa Jurja Strossmayera u Osijeku, a partneri Katedra za mađarski jezik i književnost bajske Visoke škole Jószef Eötvös te mađarska nakladnička kuća Jelenkor iz Pečuha. Prema riječima priređivača I. Trojana, projekt je bio zamišljen i realiziran kao poku-

${ }^{21}$ Stoga bismo se s pravom mogli zapitati zašto u pojedinim sredinama i na pojedinim jezicima izbori hrvatske drame nisu ostvareni, napose u Hrvatskoj susjednim državama.

22 S. NiKČević: Nov pesimizam. U: Antologija na novata hrvatska drama. Skopje 2002, s. 5-16. i B. Pavlovski: Nova hrvatska drama na makedonskom jeziku. „Republika“ 2003, br. 59 (4), s. 10-108. 
šaj hrvatskih i mađarskih književnih znanstvenika i teatrologa da se putem antologijskih izbora mađarske i hrvatske proze, poezije, drame te književne kritike i publicistike sagleda suvremena književna i književnoznanstvena proizvodnja u objema državama/regijama ${ }^{23}$.

Pojam suvremenosti u odabranim se zbirkama gotovo uvijek odnosi na razdoblje od 1990. godine do danas, s time da se recentnije zbirke dodatno usredotočuju na prvo ili čak drugo desetljeće novoga tisućljeća. Samo u izboru Nataše Govedić, čiji odabir izdvaja i njegova hrestomatijska narav, suvremenost počinje drugim desetljećem 20. stoljeća, no i kod nje u konačnom zbroju kvantitativnu prevagu odnose drame napisane nakon 1990. godine, a integralno doneseni dramski tekstovi koje autorica drži tematski reprezentativnima za hrvatsku književnost početka 21. stoljeća napisani su nakon 1990. godine ${ }^{24}$. Izborom zahvaćena razdoblja i pretpostavka su i posljedica polazišnih i konceptualnih odluka priređivača o prirodi i sadržaju njihovih konačnih dramskih izbora. Naime, u naslovima i podnaslovima te predgovorima izbora hrvatskih drama na stranim jezicima nerijetko se variraju riječi „izbor" ili „antologija“, ali tek s površnim uzimanjem u obzir terminološke težine upotrijebljenog pojmovlja s obzirom na ono što pojedina zbirka želi i umije ponuditi ${ }^{25}$. U većini slučajeva uporabu pojma antologija, koji nerijetko izaziva prijepore o opravdanosti koncepcije te o tome što antologija zapravo jest ili bi trebala biti i potiče spekulacije o drugim potencijalnim izborima, stoga ne treba tumačiti obavezujuće i doslovno, jer se većina izbornika u predgovorima i popratnim tekstovima ili očitovanjima nastojala odmaknuti od antologijskih pretenzija, s većom ili manjom osviještenošću i s većom ili manjom eksplikativnošću stavljajući u prvi plan subjektivnost i osobne preferencije, parcijalno zahvaćanje, tematsku usmjerenost te kontek-

${ }^{23}$ Tijekom projekta suradnici su realizirali devet knjižnih projekata: Jelencore. Antologija suvremenog mađarskog pjesništva (priredio Zoltán Ágoston); Kronika melankolije. Antologija hrvatskih postmodernih pjesnika (priredio Goran Rem); Valoviti Balaton. Antologija suvremene mađarske novele (priredio Zoltán Ágoston); I Drava teče... Slavonska kratka proza (priredila Helena Sablić Tomić); Tradicija, jezik, pripovijedanje. O individualnim kanonima suvremene mađarske (kratke) proze (autor Zoltán Medve); Suvremena hrvatska književnost. Poezija i kratka proza od 1968. do danas (priredila Helena Sablić Tomić i Goran Rem); Od rituala do medija. Mađarska drama na prijelazu tisućljeća (autor Péter Müller); Tranzit. Izbor iz suvremene hrvatske dramske produkcije (priredio Ivan Trojan).

${ }^{24}$ K. Cuculić: Hrvatsku dramu ne treba predstavljati kao da su u pitanju narodne kobasice (razgovor s Natašom Govedić. „Novi list“, 20.12.2013, mrežno izdanje, http://www.novilist.hr/ Kultura/Knjizevnost/Natasa-Govedic-Hrvatsku-dramu-ne-treba-predstavljati-kao-da-suu-pitanju-narodne-kobasice [pristup: 24.05.2019].

${ }_{25}$ Prvi izbornik suvremene hrvatske drame na hrvatskome jeziku Jasen Boko svoj je izbor više puta nazivao svojevrsnom ",antiantologijom“, ciljajući upravo na subjektivnost svoga odabira. 
stualnu i kulturološku uvjetovanost vlastitih odabira karakterističnu, prema suvremenim teorijskim tumačenjima, za ispisivanje književnopovijesnih radova i povijesti književnosti uopće ${ }^{26}$. Neovisno o konačnoj provedbi željenoga koncepta, Sanja Nikčević jedina se, rekla bih, zadržala na uzimanju pojma antologija kao reprezentativnog zbira djela „trajne vrijednosti“ kako, pojednostavljeno rečeno, antologiju definiraju aktualni književni pojmovnici i enciklopedije ${ }^{27}$. Imajući u vidu različite moguće vrste antologijskih izbora, nacionalne, regionalne, geografske, monografske, generacijske, tematske, žanrovske, vrsne, poetičke, svjetonazorske, manjinske, rodne, definirane periodom, upućene određenim društvenim skupinama ili slojevima, i slično, ključni pojmovi i sintagme koje se nerijetko ponavljaju u predgovorima priređivača ili između njihovih redaka - "presjek“, "predstavljanje“, ,izbor", "subjektivan odabir", "osoban izbor", "pregled", "panorama" - mogli bi upućivati na arbitrarnost kriterija odabira, no pomniji uvid u autoreferencijalne osvrte i same izbore svjedoči ipak o razmjerno čvrstom sustavu mjerila, ugrubo determiniranim profesionalnim predispozicijama, vrijednosnim sklopovima i afinitetima priređivača, zahvaćanjem biranih vremenskih odsječaka, obraćanjem ciljanim skupinama ili vrstama recipijenata i kulturnih sredina te obilježenošću širim kontekstom izdavačkoga projekta odnosno suradnika. S obzirom na učestalo akceptiranje kriterija izvođenosti, publiciranja, nagrađivanosti, međunarodnoga odjeka, kao i kritičke i teorijske recepcije, zacijelo bi se moglo govoriti i o kriterijima kanonizacijskoga potencijala ${ }^{28}$. Pritom ne treba zaboraviti da su kriteriji i učinci novijih izbora dijelom zadani i dosezima prethodnih obavljenih izbora, prijevoda i izvedbi, koliko i potrebom da se u odnosu na njih načini iskorak ili pomak, ako ne i revizija ili reinterpretacija postojećega materijala. U samim naslovima i podnaslovima većine izbora i/ili u naslovima predgovornih tekstova i izborničkih/uredničkih uvodnika, uočljive su i neke ključne riječi ili sintagme koje čitatelja mogu uputiti na kategorije mišljenja djelatne u pozadini načinjenih izbora: „novi pesimizam" Sanje Nikčević, „različiti glasovi“ Borisa

${ }^{26}$ I. Žužul: Izmišljanje književnosti. Učinci fikcije u povijestima hrvatske književnosti. Zagreb 2019.

${ }^{27}$ Hrvatska enciklopedija, primjerice, kaže: „Svrha je antologija pohrana i prezentacija književnih ili drugih tekstova trajne vrijednosti.“ Antologija. U: Hrvatska enciklopedija. Zagreb 2018, mrežno izdanje, http://www.enciklopedija.hr/natuknica.aspx?id=3144 [pristup: 23.05.2019]. Vinko Brešić u Hrvatskoj književnoj enciklopediji također navodi da je svrha antologije "pohrana i prezentacija književnih ili drugih tekstova trajne vrijednosti". V. Brešić: Antologija. U: Hrvatska književna enciklopedija. A-Gl. Knj. 1. Zagreb 2010, s. 46.

${ }^{28}$ Usp. M. Petranović: Kazalište i (pri)povijest. Ogledi o hrvatskoj kazališnoj historiografiji. Zagreb 2015. i M. Petranović: Karika koja nedostaje. Procesi kanonizacije i suvremena hrvatska drama. U: Komparationa povijest hrvatske književnosti. Književni kanon. Knj. 20. Split-Zagreb 2018, s. 196-212. 
Senkera, Kootzova „obitelj“, Trojanov „tranzit“, „cirkuska parada“ Nataše Govedić, „intimno i javno“ Darka Lukića te na kraju još jednom „različiti glasovi“ Željke Turčinović koji ovaj put imaju u vidu mlađi, novomilenijski naraštaj hrvatskih dramskih pisaca tematski okupljen oko obitelji i muškoženskih odnosa, a formalno oko šireg raspona poetika sve više usmjerenih dramskome eksperimentu i tzv. pismu za izvedbu.

Sanja Nikčević svoj je odabir dramskih djela za makedonsku sredinu zasnovala na uočenoj potrebi da nakon ratom izazvanoga prekida nekoć čvrstih i prohodnih hrvatsko-makedonskih kazališnih veza upozna makedonsku kazališnu publiku s reprezentativnim ostvarenjima hrvatske dramske književnosti kraja osamdesetih i devedesetih godina 20. stoljeća, nastojeći dati relevantan „presjek“ plodnih i raznovrsnih dramskih rukopisa koji su obilježili hrvatsko kazalište devedesetih godina ${ }^{29}$. Usredotočujući se na autore koji su na scenu stupili u osamdesetima i devedesetima te apostrofirajući dominaciju drama $t z v$. „novoga pesimizma“, prema čemu i naziva svoj predgovor, Nikčević nastoji uputiti čitatelja i u ostale rukavce hrvatske dramske proizvodnje zadanoga razdoblja, kao i smjer(ov)a kojim se hrvatska drama nastavila kretati izvan vremenskih granica njezinoga izbora, učvršćujući i periodizacijsku podjelu hrvatske drame devedesetih na mladu i novu ${ }^{30}$. Pritom se ipak zadržava na dramatičarima i dramskim djelima koji su najšire prihvaćeni u kritici i teoriji (tiskani, nagrađeni, i sl.) i vrednuje ih iz vizure njihove kazališne zastupljenosti i prihvaćenosti, nudeći relevantan presjek, a ne isključivo osobni odabir.

Boris Senker se u svome izboru, na što upućuje već i sam naslov, Different voices, rukovodio željom da kazališnoj zajednici izvan hrvatskih granica predstavi osam različitih dramskih rukopisa i osebujnih autorskih ličnosti te osam jedinstvenih kazališnih poetika koje uvršteni dramski tekstovi pretpostavljaju ${ }^{31}$. Svjestan da bi i drukčije kombinacije autora i drama mogle potpuno legitimno predstavljati hrvatske dramske devedesete, Senker $\mathrm{u}$ predgovoru ${ }^{32}$ upozorava da njegovih osam odabranih djela i nije birano po tome ključu te je stoga najprije opisao sve ono što njegov izbor nije - dio koji predstavlja veću cjelinu, jedan naraštaj dramskih pisaca, je-

29 S. NiкČEvić: Nov pesimizam. U: Antologija na novata... Skopje 2002, s. 5-16. Navodi prema hrvatskom izvorniku Sanje Nikčević kojoj ovom prigodom zahvaljujem na ustupljenom tekstu.

${ }^{30}$ Usp. A. Lederer: Vrijeme osobne povijesti. Zagreb 2004 i A. CAR Minec: Mlada hrvatska drama (ogledi). Osijek 2006.

${ }^{31}$ Analizirajući zbirku, Maria Ignatieva zaključuje da Senkerov izbor kazališnim praktičarima omogućuje dobar uvid u suvremenu hrvatsku dramu. M. Ignatieva: Links in the Chain. U: Dani hvarskoga kazališta. Četiri desetljeća dana hvarskoga kazališta. Knj. 40. Split-Zagreb 2014, s. 365-373.

${ }^{32}$ B. SenKer: Foreword. U: Different voices. Zagreb 2003, s. 7-22. 
dinstveni pokret ili dominantni dramski model. Njegov se ne poglavito tiče bilo kojega odabira kojemu bi jedina nakana bila objedinjavanje značajnih čvorišta hrvatske povijesti, kulture, književnosti i kazališta: osam tekstova odabrano je iz uvjerenja da oni nisu tek tipično hrvatski proizvod i da mogu opstati i izvan svog izvornoga i matičnoga konteksta. Ne niječući da se pojedini kodovi mogu odčitati tek na pozadini hrvatske zbilje, Senker inzistira na tvrdnji da je vrijednost odabranih drama upravo u tome što specifično „hrvatski“ dramski sloj tvori tek jedan njihov segment i da teme, likovi, ideje i osjećaji odabranih drama nadilaze okvire države u kojoj su nastale kao i kulturnih stereotipa o državi u kojoj su nastale, odnosno odustaje od oblikovanja identiteta i kulturnih stereotipa uvriježenog za žanr, primjerice, povijesti književnosti, putem žanra antologije ${ }^{33}$. Oblikujući izbor oko potencijalnog recipijenta, a to su inozemni redatelji, glumci, dramaturzi, kritičari, prevoditelji ili riječju - kazalište, i usredotočujući se na plasiranje hrvatskih dramatičara na inozemnu kazališnu scenu u najširem smislu, odabrao je engleski jezik: ne da bi se ciljalo na kazališta engleskoga govornoga područja, premda ni ona nisu isključena, već da bi se sredinama u kojima je engleski jezik prihvatljiv kao posrednik omogućio pristup hrvatskim dramskim djelima. Budući da ga prvenstveno zanima što odabrane drame mogu značiti inozemnoj publici, a ne što i zašto one znače hrvatskoj publici, interpretaciju dramskih djela, za razliku od Sanje Nikčević ili kasnije Ivana Trojana, ostavlja po strani prepuštajući čitatelju da sam o njima donosi sudove, a da ga prethodno ne optereti ili usmjeri unaprijed zadanim interpretacijama. Da spomenuti dramski tekstovi ipak ne bi ostali izvan bilo kakve kontekstualizacije, u Senkerovu je predgovoru nešto više pozornosti posvećeno političkom, ekonomskom, socijalnom, kulturnom i napose kazališnom okružju iz kojega su ponikli, što je kako smo vidjeli u slučaju S. Nikčević, a kako će biti slučaj i kasnije, primjerice kod Željke Turčinović, višekratna praksa.

Za razliku od prvih dvaju izbora koji, kako je rečeno, s jedne strane teže reprezentativnosti, a s druge različitosti zastupljenih dramskih poetika, nekoliko sljedećih izbora naglašeno je odcijepljeno od ideje presjeka ili metonimijskoga uspostavljanja dijela za cjelinu te je problemski usidreno i konceptualno organizirano oko pojedinih središnjih okosnica - obitelji, tranzicije, cirkusa te sjecišta intimnoga i javnoga. Prvi u nizu, Kootzov izbor hrvatske drame za njemačko govorno područje, naslovom upućuje na obitelj kao tematsko i problemsko čvorište oko kojega je izbor drama sačinjen, pri čemu se eufemistički poziva na jedno od potpoglavlja u također uvrštenoj drami Nine Mitrović Komšiluk naglavačke (,Jebeno sretna familija“), i okuplja pomno

${ }^{33}$ O tome usp. D. Oraić Tolić: Hrvatski kulturni stereotipi. Diseminacija nacije. U: Kulturni stereotipi. Koncepti identiteta u srednjoeuropskim knjižeonostima. Zagreb 2006. 
probrana hrvatska dramska djela koja tematiku redovito urušenoga nukleusa društva - obitelji - sagledavaju kroz očište ratnih sukoba, agresija i trauma s kojima se suočavalo hrvatsko društvo devedesetih. Kako u „Predgovoru izdavača" napominje W. Kootz ${ }^{34}$, Matišićeva Posmrtna trilogija, Vidićev Veliki bijeli zec, Komšiluk naglavačke Nine Mitrović, Mihanovićeva Žaba i Fragile! Tene Štivičić nisu odabrani da bi bili presjek hrvatske kazališne scene, već da bi nastavili svojevrstan slijed Austriji poznatih hrvatskih tekstova koji su 2002. nagrađeni na natječaju bečkoga kazališta Theater $\mathrm{m}$. b. H. za najbolju dramu s područja bivše Jugoslavije - Susjede Zorice Radaković i Zaštićene zone Damira Šodana te njihovih srodnika iz regije - neuvijeno i s nedvosmislenih kritičkih pozicija progovarajući o ratu, nacionalizmu, tranziciji i njihovim razornim posljedicama na društvo u cjelini i obitelj kao njegovu temeljnu jedinicu. Kootzov je odabir pritom nedvosmisleno obilježen uvjerenjem da su misli i nade odabranih hrvatskih dramatičara dio zajedničkog suočavanja s europskim razvojnim procesom budućnosti ${ }^{35}$. Iako odabir navedenih tekstova, redom napisanih u nultim godinama novoga tisućljeća koji ratne i poratne devedesete sagledavaju s vremenske distance i s kritičkim odmakom, u okviru zadane koncepcije ni po čemu nije sporan, upravo suprotno, donekle se spornom čini nešto slabija upoznatost priređivača s poviješću i suvremenošću hrvatske dramske književnosti i kazališta, što je ostavilo traga i na polaznim premisama i na izvedenim zaključcima ${ }^{36}$.

Pozivajući se na teorije hrvatskoga sociologa Aleksandra Štulhofera ${ }^{37}$, Tranzit Ivana Trojana također se konceptualno organizira oko naslovom naznačenog pojma tranzicije, a utemeljenje za odabir dramskih tekstova pronalazi u tezama o eskapizmu hrvatske drame prve polovice devedesetih i čvrstoj međupovezanosti suvremenoga hrvatskog dramskog pisma i zbilje od druge polovice devedesetih godina nadalje koju su u svojim studijama

${ }^{34}$ W. Коотz: Vorwort des Herausgebers. U: Eine Verdammt Glückliche Familie. Beč 2009, s. $11-14$.

${ }^{35}$ Ibidem, s. 14. Usp. i J. Marinić: Die kleine Revolution der neuen Autorengeneration Kroatiens. U: Eine Verdammt Glückliche Familie. Beč 2009, s. 15-19.

${ }^{36}$ Primjerice, politikantska kontekstualizacija drama u uvodnim tekstovima W. Kootza i J. Marinić koji mjestimice ne oskudijevaju ni faktografskim pogreškama u grubom pojednostavljivanju društveno-političkih okolnosti, ni interpretativnim promašajima u tumačenju organizacije kazališnoga života, kazališnih repertoara i dramskoga pisma od devedesetih nadalje, a napose interpretiranjem odabranih dramatičara mlađega naraštaja kroz prizmu oponiranja nekoj imaginarnoj, amorfnoj i neodređenoj staroj autorskoj gardi ideološki pristranih, formalno zastarjelih i metaforično nepristupačnih hrvatskih dramskih pisaca.

37 I. Trojan: Tranzit. Válogátas a kortárs horvát drámatermésből. U: Tranzit: Kortárs horvát drámák antológiája. Pecs 2012, s. 5-11. Navodi prema hrvatskom izvorniku Ivana Trojama, kome ovom prigodom zahvaljujem na ustupljenom tekstu. 
utvrdili Jasen Boko i Ana Lederer $^{38}$, te je u tome ključu i birana i interpretirana većina drama obuhvaćenih Trojanovim izborom. No, posebice značajnu stavku Trojanova izbora, pored prvoga objavljivanja drama Elvisa Bošnjaka Nosi nas rijeka i Borisa Senkera (P)lutajuće glumište majstora Krona, čini svojevrsna decentralizacija odabranih autorskih rukopisa te uključivanje dvaju dramatičara čija su djela unijela bitne pomake ne samo u regionalne kazališne sredine, već i u nacionalno kazalište u cjelini, a redom su izostavljana iz dotadašnjih antologijskih ili preglednih sumiranja: misli se ponajprije na Osječanina Davora Špišić čiji je Jug II uz to doveden u vezu s dramom krvi i sperme kao domaći priključak na međunarodno priznati trend, te na Splićanina Elvisa Bošnjaka čija je drama Nosi nas rijeka pročitana kao središnji primjer novoga scenskog realizma i povratka klasične dramske strukture na suvremenu hrvatsku kazališnu scenu.

Posve suprotno dvojici netom spomenutih izbornika suvremene hrvatske drame koji su svoje izborničke pozicije komentirali tek vrlo stidljivo i iz prikrajka, priređivačica hrestomatijskoga izbora hrvatske drame za francusku sredinu, Nataša Govedić, i u medijskim je istupima i u znanstvenom je rezimiranju procesa $\mathrm{i}$ ishoda sastavljanja izbora dramskih djela na stranome jeziku nastojala apostrofirati potrebu tzv. „interventnoga“ autorskog pristupa prebiranju i organiziranju materijala te naglašeno problemskog i kritičkog vrednovanja građe ${ }^{39}$. Konceptualni filter za hrvatsku dramsku produkciju 20. i početka 21. stoljeća N. Govedić pronašla je u ideji "cirkuske parade“, kako glasi i naslov izbora, i fokusu na autore koji možda nisu toliko popularni i komercijalni koliko sadržajno provokativni i skloni istraživanju dramske i kazališne forme, rukovodeći se stručnim, autorskim i umjetničkim prije nego populističkim i tržišnim kriterijima: „Smatrala sam da hrvatsku dramu ne treba predstavljati kao da su u pitanju hrvatske narodne kobasice, dakle nisam htjela uvrstiti one najprodavanije i najpopularnije, nego sam izabrala autore koji odskaču upravo kao eksperimentatori i mislioci pozornice, ljudi od izrazito provokativnog pera koji su svojevrsnom drskošću dramske situaciju koju uspostavljaju sposobni sustavno testirati i hrvatsku i francusku javnost ${ }^{\prime 40}$. Odabrani postupak donekle je odredilo i izdavačevo deklarativno nepristajanje na bilo kakvu vrstu neutralnosti u selektiranju građe, tim više

38 J. Воко: Hrvatska drama devedesetih. U: Nova hrvatska drama. Zagreb 2002, s. 5-28 i A. LeDERER: Vrijeme osobne povijesti. Zagreb 2004.

${ }^{39}$ N. Govedić: Konfliktni kriteriji zajedništva ili kako antologizirati dramske pisce. U: Krležini dani u Osijeku 2016. Hrvatska drama i kazalište u inozemstou, drugi dio, Zagreb-Osijek 2017, s. 300-308.

${ }^{40}$ K. Cuculić: Hrvatsku dramu ne treba predstavljati kao da su u pitanju narodne kobasice (razgovor s Natašom Govedić). „Novi list", 20.12.2013, mrežno izdanje, http://www.novilist.hr/ Kultura/Knjizevnost/Natasa-Govedic-Hrvatsku-dramu-ne-treba-predstavljati-kao-da-suu-pitanju-narodne-kobasice [pristup: 24.05.2019]. 
što je inicijativa za projekt, kako naglašava autorica, potekla iz francuske, a ne hrvatske glave, ali i što su suautori izbora bili izdavač Dominique Dolmieu i Miroslav Lazin. Nataša Govedić u svome predgovoru i popratnim tekstovima (biografije pisaca, analize drama) zastupa i slijedi stajalište da antologije ne bi trebale izbjegavati politički kontekst što nužno prati antologičarske i izborničke poslove, prozivajući prethodne izbore zbog odustajanja od preciziranja političkoga aspekta odabranoga dramskog materijala i potencirajući iznošenje političke i ideološke popudbine pojedinih dramskih djela i autora, primjerice, S. Šnajdera, M. Matišića ili P. Lucića: neigranje Šnajdera u devedesetima te njegovo problematiziranje etičkih i umjetničkih pitanja s kojima se hrvatsko javno mnijenje teško nosi(lo), problemi oko uprizorivanja Matišićevih Anđela Babilona i Svećenikove djece, skidanje s repertoara splitskoga kazališta Lucićeva $A z i z a^{41}$. N. Govedić upozorila je i na ulogu dramskih autora u sastavljanju antologija, napominjući kako neki suvremeni dramski radovi nisu mogli biti uvršteni u njen izbor jer pojedini autori, poput spisateljice Lade Kaštelan, nisu pristali na odabranu interpretaciju i nametnuti kontekstualni okvir antologije.

Većini priređivača hrvatskih drama na stranim jezicima bilo je važno učiniti ciljanoj kulturnoj sredini dostupnim što veći broj hrvatskih drama, odnosno veći broj drama istoga hrvatskoga autora, pa su se nerado upuštali u ponavljanje u ciljanome jeziku već prevedenih dramskih djela. Postupak je dobro vidljiv na primjeru poljske antologije hrvatske suvremene drame koja je, za razliku od ostalih, imala umnogome prijevodni karakter i koja je oblikovana prema hrvatskome izboru Odbrojavanje L. Rafolta ${ }^{42}$. Iz izbora je izostavljena Žena bomba Ivane Sajko, drama koja je već bila prevedena na poljski jezik i koja je još 2009. objavljena u časopisu „Dialog“. Iz poljskog je odabira izostao i Senkerov Fritzspiel, zacijelo zbog jake intertekstualne veze s dramskim predloškom Miroslava Krleže o obitelji Glembay koja bi poljskom čitatelju bila teže razumljiva, kao i Vidićev Veliki bijeli zec o ratnoj traumi pojedinca i društva, što donekle iznenađuje ima li se u vidu kontekst pojačanoga interesa poljskoga kazališta za hrvatske dramske tekstove ratne tematike ${ }^{43}$. Izostavljene su drame nadomještene drugim, na poljskom jeziku

${ }^{41}$ N. Govedić: Introduction. Le drame Croate, parade de cirque. U: Une parade de cirque. Paris 2012, s. 7-35.

${ }^{42}$ L. MaєczaK: O Kroatywnych... i polskich przekładach dramatu chorwackiego orazobecności literatury chorwackiej na scenach polskich po 1990 roku. U: IDEM et al.: Kroatywni. Dramat chorwacki po 1990 roku. Wybór tekstów..., s. 253-261. Na predstavljanju knjige Odbrojavanje u Hrvatskoj kao jedan od ciljeva knjige istaknuto je i približavanje novijih domaćih dramskih djela inozemnim slavistima.

${ }^{43}$ P. Gverić Katana: Od hrvatske Bridget Jones do novog pesimizma. U: Krležini dani u Osijeku 2016. Hroatska drama i kazalište u inozemstvu, drugi dio. Zagreb-Osijek 2017, s. $166-179$. 
dotad nedostupnim dramskim tekstovima Borivoja Radakovića, Marijane Nole i Dubravka Mihanovića, čime je ispunjen temeljni cilj antologije: upoznavanje domaćega čitatelja s novijim strujanjima u hrvatskoj drami i popunjavanje kulturoloških praznina nastalih do tada tek manjim brojem poljskih prijevoda suvremenih dramskih autora ${ }^{44}$.

U dvama sljedećim izborima, a riječ je o dvjema zbirkama hrvatske drame na španjolskome jeziku, uvršteno je više istih dramatičara, ali su u svakoj zbirci zastupljeni različitim dramskim djelima, razotkrivajući istodobno i tendenciju predstavljanja različitih radova istoga autora, i tendenciju predstavljanja novijih autorskih rukopisa i dramskih naraštaja u odnosu na postojeće i prethodeće izbore hrvatskih autora i drama. Za razliku od poljske antologije koja se više obraćala čitateljima i proučavateljima hrvatske književnosti, kulture i jezika, te joj je takva bila i recepcija, s najviše odjeka u znanstvenim proučavanjima hrvatske drame a gotovo zanemarivom u poljskom kazalištu ${ }^{45}$, izbori na španjolski jezik, napose izbor Željke Turčinović, izravnije su težili kazalištu i kazališnoj publici nego čitateljima ili akademskoj zajednici, dijelom i zbog pripadnosti urednika i priređivača u prvome redu kazališnome miljeu. Dva izbora suvremene hrvatske drame na španjolskome načinjena u razmaku od svega četiri godine proizvod su gotovo istoga autorskoga tima, Darka Lukića i Željke Turčinović u ulozi urednika i/ili izbornika te Nikoline Židek u ulozi prevoditeljice i inicijatorice projekata, i oba su značila velik iskorak u predstavljanju suvremene hrvatske drame $u$ španjolskome govornome području, otvorivši puteve i izvedbama hrvatskih drama i daljnjem situiranju hrvatskih autora $\mathrm{u}$ kazališnom prostoru španjolskoga govornog izričaja.

U prvome izboru hrvatskih drama na španjolskome Darko Lukić je, naglašavajući originalnost odabranih tekstova i autorskih glasova, zajednički nazivnik pronašao u postupku „iskazivanja velikih, gotovo globalnih problema kroz posve intimna očišta“ i u tom što „progovaraju javno o intimnom, svjedoče javno o posve osobnom ${ }^{\prime 46}$, a unatoč generacijskim, tematskim, stilskim i estetičkim različitostima među autorima, poveznicu je pronašao i u osjetljivosti dramskih autora prema vremenu i prostoru u kojem stvaraju i društvenokritičkome angažmanu koji ih odvaja od dramskoga pisma

${ }^{44}$ L. Małczak napomenuo je da su u poljskim prijevodima hrvatski dramski tekstovi najslabije zastupljen književni rod (npr. samo je časopis „Dialog“ objavio nekoliko prijevoda hrvatskih suvremenih dramatičara, a Miro Gavran zastupljen je dvjema samostalnim knjigama drama).

45 P. Gverić Katana: Od hrvatske Bridget Jones... U: Krležini dani... Zagreb-Osijek 2017, s. $166-179$.

${ }^{46}$ D. Lukić: Lo público sobre lo íntimo, lo intimo sobre lo público. U: Siete dramas croatas contemporaneos. Buenos Aires 2013, s. 9-11. Navodi prema hrvatskom izvorniku Darka Lukića kome ovom prigodom zahvaljujem na ustupljenom tekstu. 
devedesetih. Sam će, međutim, naglasiti kako ponuđeni izbor drama smatra tek izrazito parcijalnim i vrlo osobnim uvidom u stanje suvremene hrvatske dramske produkcije. Valja ipak reći da su na Lukićev popis uvršteni autori i tekstovi koji su i ranije nalazili put do hrvatskih dramskih antologija, a mahom se tiču drame nastale od 2000. do trenutka izbora, te autori i tekstovi koji su većinom ovjereni nagradama ili domaćim i međunarodnim izvedbama (Žaba, Komšiluk naglavačke, Žena bomba, Fragile!, Moj sin samo malo sporije hoda), dakle autori/tekstovi određenih kanonskih vrijednosti. Osobitost ovoga izbora svakako je i uvrštavanje drame Stranci samoga izbornika koji je svojim prethodnim djelima (Vampiri, Važno je biti pozitivan) već ostvarivao zamjetne uspjehe $u$ kazalištu španjolskoga govornog područja.

Govoreći o svom izboru, Željka Turčinović radikalno je izmijenila dotadašnju perspektivu gledanja na hrvatske dramske antologije na stranim jezicima, obrnuvši žal zbog nemogućnosti predstavljanja presjeka cjelokupne aktualne produkcije $u$ zadovoljstvo mogućnošću višestrukih potencijalnih izbora i predstavljanja raznolikoga bogatstva suvremenoga hrvatskog dramskog pisma. U uvodnome je tekstu, slično B. Senkeru, ponudila španjolskome čitatelju kratki pregled povijesti hrvatske drame i kazališta, i to od samih začetaka hrvatske dramske riječi u srednjovjekovlju do suvremenosti, no u samom se izboru fokusirala na posve recentnu dramsku produkciju, što afirmiranih hrvatskih dramatičara zrelije (Lada Kaštelan, Mate Matišić) i srednje generacije (Tomislav Zajec, Nina Mitrović), što mlađega dramskoga naraštaja (Ivor Martinić, Vedrana Klepica), filtrirajući djela s obzirom na njihovu potencijalnu tematsku zanimljivost španjolskoj publici, ali i univerzalnu prepoznatljivost na razini suvremene problematike (obitelj, ljubav) i dramske forme (ne samo klasična dramska struktura već i domaći izdanci tzv. pisma za izvedbu kao odjeka šireg međunarodnog fenomena u tradiciji postdramskoga kazališta ${ }^{47}$.

S obzirom na pozicioniranje postojećih izbora suvremene hrvatske drame na stranim jezicima prema univerzalnosti ili specifičnosti odabrane tematike, klasičnoj ili eksperimentalnoj dramskoj formi, društvenome angažmanu, odnosu prema politikama identiteta, u prvome redu nacionalnih, kazališnoj praksi te nacionalnome književnome kanonu, postojeći odabiri nedvojbeno svjedoče o tome kako sami sebe vidimo i na koji se način i čime želimo predstaviti drugima te o (vlastitom) poimanju književne i kazališne vrijednosti, koliko i o uvjetima koje nam (izvana) nameće mogućnost izlaska $\mathrm{u}$ druge kulturne i nacionalne sredine (poetička inovativnost, komparativno srodni priključci na međunarodna strujanja, uža ratna tematika, žensko pismo, univerzalna problematika...).

47 Ž. Turčinović: Diferentes voces de la escritura dramática croata. U: Teatro Croato Contemporaneo. Madrid 2017, s. 9-15. Navodi prema hrvatskom izvorniku Željke Turčinović kojoj ovom prigodom zahvaljujem na ustupljenom tekstu. 
Dosadašnji su se izbori velikim dijelom oblikovali prema pretpostavljenoj i priželjkivanoj recepciji u ciljanoj kulturi, težnji za predstavljanjem tematski i poetički što heterogenijega dramskog materijala i osobnim preferencijama priređivača, a mnogo manje prema književnom kanonu vlastite nacionalne kulture koji, kada je riječ o suvremenoj hrvatskoj drami, u matičnoj kulturi zapravo nikada nije ni zamišljen ni uspostavljen. Štoviše, moglo bi se čak reći da temeljitijih i obuhvatnijih pokušaja u tome smjeru dosada nije ni bilo te je i većina domaćih antologija i izbora suvremene hrvatske dramske produkcije bila tek sporadična, fragmentarna i parcijalna s obzirom na vrijeme koje zahvaćaju (ili samo devedesete, ili samo nulte, ili samo recentnu produkciju), na učestalo generacijsko fokusiranje na dramatičare stasale od osamdesetih i devedesetih naovamo i izostavljanje dramatičara koji su ranije započeli svoje karijere, ali nisu prestali stvarati u predmetnome razdoblju (Brešan, Šnajder...), na izričito rukovođenje osobnim ukusima i preferencijama priređivača, na tematsku i žanrovsku selekciju građe (primjerice, antologije ratne drame i poratne drame, ratne komedije i sl. kakve je priređivala S. Nikčević), te na necjelovitost biografskih, bibliografskih, periodizacijskih, klasifikacijskih, žanrovskih, poetičkih ili izvedbenih sagledavanja, klasifikacija, vrednovanja, analiza i pristupa postojećem dramskom korpusu ${ }^{48}$. Ipak, usporede li se popisi izvedenih i objavljenih hrvatskih drama i autora od devedesete do danas s popisom autora i dramskih djela obuhvaćenih dosadašnjim izborima hrvatske drame na stranim jezicima, ne može se previdjeti prepoznatost jednog dijela istaknutijih hrvatskih autora i drama (pod pretpostavkom da je kriterij „,istaknutosti“ njihova igranost u zemlji i inozemstvu, nagrađivanost, objavljivanost, kritička recepcija...), pa i stanovito antologijsko legitimiranje pisaca i drama odnosno povratan prinos uspostavljanju nacionalnoga kanona. Pritom su pojedini autori predstavljeni više puta i većim brojem dramskih tekstova (Mate Matišić s najvećim brojem ponavljanja i najširim dijapazonom prevedenih tekstova, zatim Miro Gavran, Tomislav Zajec i Ivana Sajko te nešto manje Dubravko Mihanović, Lada Kaštelan, Tena Štivičić, Nina Mitrović, Boris Senker i Asja Srnec Todorović); neki su dramatičari zastupljeni samo jednim, ali obično najzapaženijim djelom (Milko Valent Golom Europom, Elvis Bošnjak dramom Nosi nas rijeka, a Davor Špišić dramom Jug II); manji broj dramatičara uvršten je tek jednom i umnogome predstavlja specifičnost ili iskorak pojedinoga izbora (Pavo Marinković, Tanja Radović, Borivoj Radaković, Marijana Nola); naposljetku, određen je broj suvremenih dramskih pisaca u cijelosti izostavljen iz antologijskih odabira drame na stranim jezicima.

${ }^{48}$ O tome usp. M. Petranović: Karika koja nedostaje. Procesi kanonizacije i suvremena hrvatska drama. U: Komparationa povijest hrvatske književnosti. Književni kanon. Knj. 20. Split-Zagreb 2018, s. 196-212. 
Dosad objavljene knjige hrvatskih drama mogu ukazati na neka općenitija obilježja izbora suvremene dramske produkcije na stranim jezicima, primjerice, na kulturološka i pragmatična prilagođavanja odabira novome kontekstu s obzirom na postojeće prijevode, tematsku zanimljivost ili formalnu atraktivnost $\mathrm{u}$ novoj sredini, kao i na potencijalnu razumljivost dramskoga materijala te ciljanoga recipijenta od kazališta preko čitatelja do znanstvene zajednice, ali i na stanovita razmimoilaženja u shvaćanju književne i kazališne vrijednosti u izvornoj i ciljanoj kulturi i modeliranje izbora izvana ili iznutra s obzirom na matičnu sredinu, što se dijelom podudara i s repertoarnim odabirima stranih kazališta i kazališnim izvedbama hrvatskih autora u drugim kulturama ${ }^{49}$. Valja zamijetiti i da je većina objavljenih izbora nerijetko rezultat djelovanja pojedinaca, pojedinih institucija i kontingentnih kontakta s inozemnim suradnicima srodnih strukovnih interesa, a ne obuhvatn(ij)e nacionalne strategije književnoga predstavljanja nacionalne dramske produkcije $u$ međunarodnim okvirima, $\mathrm{i}$ da stoga ne može biti govora ni o predstavljanju nacionalnoga dramskog kanona ni o predstavljanju neke osmišljene projekcije nacionalnoga književnog života, već o nerijetko osobnim i subjektivnim prebiranjima po suvremenoj dramskoj produkciji ${ }^{50}$.

S obzirom na raspon od gotovo tri desetljeća, čini se da je sazrelo vrijeme za cjelovitijim (re)valoriziranjem i (re)interpretacijama umjetničkih postignuća dramskog pisma i kazališne produkcije od devedesetih do danas, kao i rezimiranjem književnokritičkih, kazališnokritičkih i teatroloških zaključaka te za pokušajem oblikovanja kakvog-takvog kanonskog korpusa dramskih djela koji bi se dalje mogao propitivati i dopunjavati ovisno o različitim pogledima na kanonske vrijednosti, ali i usmjeravati percepciju i recepciju suvremene hrvatske dramske produkcije na stranim jezicima. Kada je riječ o recepciji suvremene hrvatske dramske književnosti u Poljskoj, vrijedi spomenuti da su u pripremi čak dva nova izbora suvremene hrvatske drame na poljskome, pa će biti zanimljivo vidjeti na koji će način navedeni izbori, što rečeno ovim radom, što svoje prethodnike - potvrditi, modificirati ili osporiti.

49 Zasebno istraživanje zaslužuje pitanje koliko su dosadašnji izbori imali odjeka na kazališne izvedbe pojedinih autora i dramskih djela u danim kazališnim sredinama, ali i u književnoj i znanstvenoj zajednici te medijima i javnosti.

${ }^{50}$ Govoreći o prijevodima hrvatske književnosti na poljski jezik, Leszek Małczak govori i o „iskrivljenoj“ slici hrvatske književnosti jer nije prevođeno ono što se u matičnoj kulturi najviše cijeni. L. MaŁczAK: O poljskim prijevodima hrvatske književnosti u razdoblju od 1990. do 2006. U: Komparativna povijest hrvatske književnosti. Hrvatska književnost XX. stoljeća u prijevodima: emisija i recepcija. Split-Zagreb 2007, s. 75-104. 


\section{Literatura}

Antologija. U: Hrvatska enciklopedija, mrežno izdanje. Zagreb, Leksikografski zavod Miroslav KRLEŽA, 2018. http://www.enciklopedija.hr/natuknica.aspx?id=3144 [pristup: 23.05.2019].

BREšIć V.: Antologija. U: Hrvatska književna enciklopedija. A-Gl. Knj. 1. Zagreb, Leksikografski zavod Miroslav Krleža, 2010, s. 46.

Воко J.: Hrvatska drama devedesetih. U: Nova hrvatska drama. Zagreb, Znanje, 2002, s. 5-28.

Воко J.: Nova hrvatska drama. Zagreb, Znanje, 2002.

CAr Minec A.: Mlada hrvatska drama (ogledi). Osijek, Matica hrvatska Ogranak Osijek, 2006.

Cuculić K.: Hrvatsku dramu ne treba predstavljati kao da su u pitanju narodne kobasice (razgovor s Natašom Govedić). „Novi list“, 20.12.2013, mrežno izdanje, http://www.novilist. hr/Kultura/Knjizevnost/Natasa-Govedic-Hrvatsku-dramu-ne-treba-predstavljatikao-da-su-u-pitanju-narodne-kobasice [pristup: 23.05.2019].

Ignatieva M.: Links in the Chain. U: Dani hoarskoga kazališta. Četiri desetljeća dana hvarskoga kazališta. Knj. 40. Split-Zagreb, HAZU, Književni krug, 2014, s. 365-373.

Govedić N.: Konfliktni kriteriji zajedništva ili kako antologizirati dramske pisce. U: Krležini dani u Osijeku 2016. Hrvatska drama i kazalište u inozemstou, drugi dio. Zagreb-Osijek, Odsjek za povijest hrvatskog kazališta HAZU, HNK u Osijeku, Filozofski fakultet u Osijeku, 2017, s. 300-308.

Govedić N.: Introduction. Le drame Croate, parade de cirque. U: Une parade de cirque. Paris, L'Espace d'une instant, 2012, s. 7-35.

Govedić N.: Une parade de cirque. Paris, L’Espace d'une instant, 2012.

Greenblatt S.: A mobility studies manifesto. U: Idem et al.: Cultural Mobility: A Manifesto. Cambridge, Cambridge Universtiy Press, 2009, s. 250-253.

Gverić Katana P.: Od hrvatske Bridget Jones do novog pesimizma. U: Krležini dani u Osijeku 2016. Hrvatska drama i kazalište u inozemstou, drugi dio. Zagreb-Osijek, Odsjek za povijest hrvatskog kazališta HAZU, HNK u Osijeku, Filozofski fakultet u Osijeku, 2017, s. 166-179.

Коотz W.: Eine Verdammt Glückliche Familie. Beč, Kaiser Verlag, 2009.

Lederer A.: Vrijeme osobne povijesti. Zagreb, Naklada Ljevak, 2004.

Lukić D.: Lo público sobre lo íntimo, lo intimo sobre lo público. U: Siete dramas croatas contemporaneos. Buenos Aires, Biblos, 2013, s. 9-11.

Lukić D.: Siete dramas croatas contemporaneos. Buenos Aires, Biblos, 2013.

Maєczak L. et al.: Kroatywni. Dramat chorwacki po 1990 roku. Wybór tekstów. Sv. 1--2. Katowice, Wydawnictwo Uniwersytetu Śląskiego, 2012.

MaєczAK L.: O Kroatywnych... i polskich przekładach dramatu chorwackiego orazobecności literatury chorwackiej na scenach polskich po 1990 roku. U: Kroatywni: dramat chorwacki po 1990 roku: wybór tekstów. Katowice, Wydawnictwo Uniwersytetu Śląskiego, 2012, s. $253-261$.

MaŁczaK L.: O poljskim prijevodima hrvatske književnosti u razdoblju od 1990. do 2006. U: Komparativna povijest hrvatske književnosti. Hrvatska književnost XX. stoljeća u prijevodima: emisija i recepcija. Split-Zagreb, Književni krug, Odsjek za komparativnu književnost Filozofskoga fakulteta Sveučilišta u Zagrebu, 2007, s. 75-104. 
Marinić J:: Die kleine Revolution der neuen Autorengeneration Kroatiens. U: Eine Verdammt Glückliche Familie. Beč, Kaiser Verlag, 2009, s. 15-19.

NiкČEvić S.: Antologija na novata hrvatska drama. Skopje, Fakultet dramskih umjetnosti, 2002.

NiKČEvić S.: Nov pesimizam. U: Antologija na novata hrvatska drama. Skopje, Fakultet dramskih umjetnosti, 2002, s. 5-16.

Pavlovski B.: Nova hrvatska drama na makedonskom jeziku. „Republika“ 2003, br. 59 (4), s. $105-108$.

Petranović M.: Karika koja nedostaje. Procesi kanonizacije i suvremena hrvatska drama. U: Komparationa povijest hrvatske književnosti. Književni kanon. Knj. 20. Split-Zagreb, Odsjek za komparativnu književnost Filozofskog fakulteta Sveučilišta u Zagrebu, Književni krug, 2018, s. 196-212.

Petranović M.: Kazalište i (pri)povijest. Ogledi o hrvatskoj kazališnoj historiografiji. Zagreb, Ex Libris, 2015.

Rafolt L.: Odbrojavanje. Antologija suvremene hrvatske drame. Zagreb, Filozofski fakultet, Zagrebačka slavistička škola, 2007.

Senker B.: Different voices. Zagreb, Hrvatski centar ITI, 2003.

Senker B.: Foreword. U: Different voices. Zagreb, Hrvatski centar ITI, 2003, s. 7-22.

Senker B.: Hrestomatija novije hrvatske drame (1941.-1995.). Zagreb, Disput, 2001.

Senker B.: Nastojanja pariškog kruga. U: Krležini dani u Osijeku 2016. Hrvatska drama i kazalište u inozemstou, drugi dio. Zagreb-Osijek, Odsjek za povijest hrvatskog kazališta HAZU, HNK u Osijeku, Filozofski fakultet u Osijeku, 2017, s. 191-211.

Trojan I.: Tranzit: Kortárs horvát drámák antológiája. Pecs, Jelenkor, 2012.

Trojan I.: Tranzit. Válogátas a kortárs horvát drámatermésből. U: Tranzit: Kortárs horvát drámák antológiája. Pecs, Jelenkor, 2012, s. 5-11.

Turčınović Ž.: Diferentes voces de la escritura dramática croata. U: Teatro Croato Contemporaneo. Madrid, Ediciones Antigona, 2017, s. 9-15.

Turčinović Ž.: Teatro Croato Contemporaneo. Madrid, Ediciones Antigona, 2017.

ŽıdeK N.: Hrvatska drama na salonu kazališne knjige u Madridu. „Kazalište“ 2018, br. 21 (75-76), s. 68-71.

ŽužUl I.: Izmišljanje književnosti. Učinci fikcije u povijestima hrvatske književnosti. Zagreb, Meandar, 2019. 